\title{
The Effects of The Multiparty Regimes on Economic Growth and The Technological Changes
}

\section{Constantin Plamadeala}

\section{ABSTRACT}

The relationship between types of multiparty regimes and economic growth represents a disputed issue in nowadays.

The aim of this essay is to examine the differences between multiparty authoritarian regimes and multiparty democratic regimes and their effects on sustainable economic growth and technological changes.

Keywords:

Political regimes, Democracy, Sustainable growth, Technology 


\section{INTRODUCTION}

The analysis of the relationship between economy and politics over time resulted in a greater understanding of how the political design affects the behavior of economic variables. Although many of the results do not converge, it is an act foreign to economics to deny the similarities between economics and politics.

Multi-party systems tend to be associated with trivial contradictions while singleparty systems are associated with graver contradictions. The second condition for a multi-party system is the mitigation of the revolutionary pressures of the working class. In Africa, these pressures remain particularly intense because of the small size of the social surplus and the extreme deprivations of the masses. The form of how a government is elected and takes its decisions has become a recurring theme in the studies of political economy.

Under this research, we interrogated the operation of a multiparty democratic and authoritarian regimes on economic development and technological transfer. Consequently, this essay provides information that will stimulate informed debate on governance issues. The essay argues that the functioning of multi-party regimes should be given attention. It is important therefore to give the following questions: First, will the multi-party regimes in general contribute to the rapid economic growth or not? Second, could multiparty regimes consolidate the sustainable growth? Third, will the political actors of the multiparty system be able to manage technological transfer that could improve the economy of the country?

\section{MFASURING THF IMULTIPARTY DFMOCRATIC AND THF TOTALITARIAN IMULTIPARTY RFGIMES}

The political institutions which include the political parties being a matter for economic performance, their influence is likely to be indirect rather than direct. Multi-party politics operates under or with active political parties. This system provides an outlet through which people can participate in the politics of their government and address the issues at hand. Parties provide a structured organized framework through which people can express political views besides permitting more points of view to be represented in government. Political parties mobilize voters on behalf of a common set of goals, norms and interests. In that way they play a crucial role in the democratic process as they formulate political agendas, select candidates and conduct elections, among others. They also link citizens and the government by providing a means by which people can have a voice in their government. It is also argued that multi-party political systems often provide stable and enduring systems of government as opposed to a one-party system.

Citizen loyalty to authoritarian regimes is constructed through a combination of public polices and economic performance; ideological appeals and indoctrination; material side-payments; and threats of violence (Magaloni, 2006).

In the definition of dictatorship, should be stated that even if elections exist in such regimes they are neither competitive nor crucial in distributing political power. Many dictatorships allow some sorts of, normally manipulated, elections, but the 
effect of these is disputed. Authoritarian regimes that manage to generate economic prosperity might enjoy genuine popular support. However, even in the absence of prosperity and stagsering economic mismanagement, authoritarian regimes can keep their subjects loyal through a combination of rewards and punishments. concept of electoral dictatorship entails a multi-party system, which should be distinguished from oneparty regimes and liberal democracies, though this is a task that would be fraught with practical ambiguities.

\section{DEVELOPMENT MEASURES OF DEMOCRATIC AND AUTHORITARIAN MULTIPARTY REGIMES.}

Development must be seen from very different aspects. It is very fashionable to see the development only from the economic point of view. This narrow view carries the danger of blinding policy makers to other aspects of development which are equally important such as development of the democratic order and social development. Indeed, all these aspects of development must be seen as inseparable and interdependent.

There is an evidence of a good relation between political regimes and economic development. Democracy is significantly less likely to break down in prosperous countries, and depending on number of years the democracy could survive increases steadily with greater levels of per capita income. Economic development is not the only factor that affects democratic regime, and the level of human development, as measured by factors such as life expectancy and literacy, appears to be more closely correlated with democracy. The economic development appears to improve the likelihood of democratic survival through its impact on different crucial intervening variables such as:

- Relationship between society and state

- Strength of civil society,

- Political culture,

- Class structure,

- Connection to the international system.

To break away from the poverty trap and initiate growth, most countries installed authoritarian development process, or an authoritarian state with economic capability. The key ingredients of this regime are as follows:

- Powerful and economically literate leader

- Development as a supreme national goal, ideology, and obsession

- An elite technocrat group to support the leader in designing and executing policies

- Political legitimacy derived from successful development

Under this type of regime, many elements of democracy such as freedom of speech and press, free and competitive election, and the power of parliament were restricted or suspended. For this reason, these regimes were regularly criticized by the West as "undemocratic." However, people may support their dictator, not because he came to power by free election, but because he delivers national security, higher income, and job opportunities to them.

\section{ANALYSIS OF THE MULTIPARTY POLITICAL REGIMES ON ECONOIMIC DEVELOPIMENT}

The economic performances (inflation, unemployment, and growth) decisively 
influence voters and their behavior, and policymakers are aiming at re-election, while those in opposition strive to win and come to power.

Therelation between economicgrowthand political factor has come as an important role for the society. Different researches on this issue has proliferated making clear that the political environment is a significant actor for the economic growth. While political institutions are affected by economic development, they are in turn key determinant of the development process.

The political institutions, set in two different countries, can affect their respective economy in different ways. And at the same time, institutions that differ politically, set in two different countries, can lead their countries to similar economic performance.

It has been already demonstrated that economic institutions (such as property rights, regulatory institutions, institutions for macroeconomic stabilization, institutions for social insurance, institutions for conflict management, etc.) represent the major source of economic growth across countries (Rodrik 2007). Among other things, economic institutions have decisive influence on investments in physical and human capital, technology, and industrial production. It is also wellunderstood that in addition to having a critical role in economic growth, economic institutions are also important for resource distribution.

\section{EFFECTS OF RFGIMES ON SUSTAINABLE GROWTH}

The extremely complex phenomena of "political regimes" and "economic growth" could be interrelated and connected in several ways. If one wants to dig deep into the question of how democratic and authoritarian regimes affects growth, one will have to reflect on arguments with genesis not only in different theoretical traditions, but also stemming from different subjects in the social sciences.

Studies exploring the effect of political regimes on sustainable growth employ different types of models, although averaging smoothens out the effect of the business cycle, it oftentimes leads to transformed conclusions linking political characteristics to economic performance that occurred at a different time.

Growth is a complex outcome in which many institutional and non-institutional factors presumably play a role. There may be situations in which strong parties mitigate growth, for example, if parties adopt ideologies that incline them to pursue growth retarding policies, such as expropriation of private capital or the suppression of market-based pricing.

Even though the literature is divided on how political regime-types impact economic growth, this essay argues that competitive multiparty democracies may unfortunately have a disadvantage in sustaining rapid, accumulation-driven growth due to leadership discontinuity and greater difficulty in maintaining a politically insulated technocracy. Moreover, single-party states are likely to have an advantage in mobilizing labor and capital for rapid economic growth, even if they do not provide an advantage in increasing total factor productivity.

It is beneficial to conceptualize demo- 
cracy as "political democracy" and "economic democracy" in the analysis of the relationship between democracy and economic growth. While multi-party system, free elections, freedom of press, participative and good governance, political stability are fundamental constituents of political democracy; free market, guarantee of the right of private ownership, minimization of the public share in economic activities, freedom in the activities of business and credit system, regulation on labour market, economic rights and freedoms constitutes main tenets of economic democracy (Barro, 1996a:1; Doucouliagos and Ulubasoglu, 2008:64)

\section{CONCLUSIONS AND EVALUATIONS}

Basically, the conclusion that we can draw from here is that every time we talk about a certain political regime and about its economic performance, we must take into account its particularities, and in the context of globalization, there must be included in the general picture the cultural turning or change to which many countries are subjected (Barnes, 2001, p. $457)$.

The political institutions play a major role regarding the economic performance as it is them that have the potential to require constraints over the economic structure and not only. It is the political institutions of the regime as such, including its particularities and the cultural turn in for establishing the political parameters not only for the economic development but also for the social development.

The economic growth and development depend on the capacity of the regime to offer a favorable environment for the individuals to invest in their economy, as investments represent one of the potential factors which sustain economic performance. 


\section{REFERFNCES}

Araujo J. M., Leite P. A., Reisj F.A. Party Ideology and Elections: An Analysis of Political-Economic Cycles in Brazilian States, Revista Espacios, Vol.37, N13, 2016

Giymah-Boadi E. Political Parties As Instrument of National Unity Development in Ghana, Governance Vol.1 No.1 May 1995

Joshi D.K. Multiparty Democracies and Rapid Economic Growth: A Twenty-First Century Breakthrough?, Research Collection School of Social Sciences, 2011

Liden G.theories of Dictatorships: Sub-Types and Explanations, Studies of Transition States and Societies, V.6 Issue 1, 2014, P.52-54

Madaleno M., Pinho C., Political Regimes and Economic Growth, Revista Enpoques Vol. Vii, No.11, 2009, P.487

Masengo J.A. Democracy or Fallacy: Discourses Shaping Multi-Party Politics and Development in Uganda, Journal of African Democracy and Development Vol. 1, Issue 2, 2017, P 120-122

Ohno K. The East Asian Growth Regime and Political Development, National Graduate Institute For Policy Studies,

Sandalcilar A. R. Democracy and Growth: Evidence from Transition Economies, American International Journal Of Contemporary Research Vol. 3 No. 1; January 2013

Shanabli J., Economic Growth and Political Regimes, 2014, Ftp://Ftp.repec.org/Opt/Redif/ Repec/Eub/Wp2014/2014-10.Pdf 